Collection: RegioResources21 - "Spatial information and participation of socio-ecological systems: experiences, tools and lessons learned for land-use planning"

Guest Editors: Daniele La Rosa, Carsten Lorz, Hannes Jochen König, Christine Fürst

\title{
How do urban dwellers react to potential landscape changes in recreation areas? A case study with particular focus on the introduction of dendromass in the Hamburg Metropolitan Region
}

\author{
Thiemen Boll, Christina von Haaren, Christian Albert
}

Recently, many German regions have seen dramatic landscape changes in agricultural areas due to increasing cultivation of bioenergy crops. Especially in regions that are economically dependent on income from recreational use, this development faces opposition by tourist stakeholders, local inhabitants and recreationists. In the future tall bioenergy plants like maize could be replaced by even taller short rotation coppice plantations of willow and poplar. This development raises the question of how people perceive landscape changes and if perceptions are influenced by the landscape where they take place. We surveyed urban residents in the city of Hamburg $(n=400)$ to see how they perceive potential landscape changes in four recreation areas with different landscape structures in the vicinity of Hamburg (Luineburg Heath, Harburg Hills, Elbe Marshes and Altes Land). The survey showed that people rated changes significantly different, depending on the specific landscape type of the recreation areas. The survey did not show a clear general preference for reducing or increasing forests. However, the landscape character of each recreation area had a strong influence on the acceptance of landscape changes by planting forests, hedges, and shrubs. People showed a significantly higher negative reaction towards more forests in open landscapes characterized by heath and meadows than in landscapes with a higher share of forests and fields. Interestingly, the introduction of hedges and shrubs was evaluated differently from the introduction of forests depending on the type of open landscape. People preferred the introduction of hedges and shrubs in the landscape rich in meadows and pastures while they rejected the introduction of hedges and shrubs in a historic cultural landscape rich in heathland. In view of these results we recommend that the landscape character and the cultivation system are considered in the assessment and determination of potential short rotation coppice production sites. This may considerably increase the acceptability of dendromass cultivation for energy purposes.

Keywords: Landscape Changes, Recreation, Landscape Character, Visual Landscape, Dendromass, Short Rotation Coppice, Agriculture, Forestry

\footnotetext{
Introduction

Rural areas in the surroundings of metropolitan regions provide various ecosystem services for the cities: they provide drinking water, support the regional supply of food, regulate and improve the regional climate, mitigate flood risks, contribute to regional identity and serve as recreation areas. Recently, the generation of renewable energies from wind, water, solar and biomass has gained new importance among ecosystem services. At the same time, rural landscapes are under pressure from various driving
}

forces such as suburbanization processes and the intensification of agricultural practice (European Commission 2007, Antrop 2004, Palang et al. 2010). Globally, increasing food and energy prices make agricultural production more profitable and land prices more expensive. These economically strong land use interests intensify pressure on the provision of less profitable ecosystem services such as public recreation and landscape aesthetics. The intensification of agricultural practice impacts greatly the visual landscape due to the removal of landscape $\square$ Institute of Environmental Planning, Leibniz University Hannover, Herrenhäuser Str. 2, D-30419 Hannover (Germany)

@ Thiemen Boll (boll@umwelt.unihannover.de)

Received: Oct 31, 2013 - Accepted: Mar 19, 2014

Citation: Boll T, von Haaren C, Albert C, 2014. How do urban dwellers react to potential landscape changes in recreation areas? A case study with particular focus on the introduction of dendromass in the Hamburg Metropolitan Region. iForest 7: 423-433 [online 2014-05-19] URL: http://www.sisef.it/ iforest/contents/?id=ifor1173-007

Communicated by: Marco Borghetti

elements, thus creating larger open spaces (Tveit 2009) and due to the conversion of grassland into fields. In Germany, the energy transition (Energiewende) intensifies pressure on rural agricultural areas due to enhanced demand for bioenergy crops (Franke 2008, Nohl 2001).

Contrary to the installation of wind and solar parks, which are immediately visible, the change from food to bioenergy crops is a more subtle and gradual process. However, this change also greatly impacts the visual and recreational functions of the landscape. Bioenergy plants like maize are generally taller than food crops in order to produce more biomass per area unit (TLL 2007). Breeding and genetic modification will make energy crops even taller in the future. This will gradually affect the visual landscape. Agricultural change becomes increasingly visible when the shift is to monoculture farming of bioenergy crops. In many German regions large-scale cultivation of maize has led to protests of citizen groups against biogas plants using maize as a substrate. Especially in regions where tourism plays an important role or in recreational areas close to cities, landscape changes that impair the attractiveness of the landscape are highly controversial and may have negative economic and social implications.

In the future the production of dendromass in short rotation coppices (SRC) of willow and poplar could be an alternative to annual energy crops such as maize. In this context we define dendromass broadly as all woody plants. SRC, in contrast to conventional forestry, is the cultivation of dendromass on agricultural fields with harvesting circles of 2-20 years. SRC has many ecological advantages compared to annual crops, such as less erosion, higher biodiversity, improved water quality and better energy input/output ratio (Bemmann 2010, Baum et al. 2009, Strohm et al. 2012). Several German research 
projects are currently developing implementation strategies to increase the cultivation of SRC to produce dendromass for energy purposes (e.g., AgroForNet, Löbestein) while other projects have already studied the economic and ecological potentials of SRC and agroforestry, finding that energy efficiency and greenhouse gas balance is considerably more positive compared to other energy crops (e.g., AgroWood, AgroForst, Dendrom, Novalis).

The potential area in Germany which could be used for SRC is estimated to be 0.5 million ha in 2030 and 1 million ha in 2050 (Nitsch et al. 2010, Thrän et al. 2011). While in the past it was not possible to plant trees on agricultural land, the new German forest law allows the cultivation of trees which are harvested on a less than 20 years rotation ( $\$$ 2, Abs. 2, S. 1, BWaldG). In addition, SRC is eligible for direct payments by the Common Agricultural Policy (CAP) of the EU (Commission Regulation EC No. 1120 2009). After the recent CAP reform SRC will be eligible within the $5 \%$ ecological focus area as decided in the final negotiations before the decision of the European Parliamen ("greening" of the first pillar of the CAP by setting-aside agricultural land for biodiversity purposes).

SRC plantations strongly influence the landscape character because they are planted on open agricultural land. As SRC plantations can grow up to 10 meters in 3 years, the character of the landscape is changed considerably. However, research on SRC generally does not take into account the impacts on the visual landscape. Knowledge gaps exist concerning how these impacts are perceived by the public. Developing this knowledge can be very helpful for designing implementation strategies for dendromass production for energy purposes in differen landscapes that avoid negative impacts and contribute to positive effects for recreational uses.

\section{Research objective and questions}

Taking into consideration the various landscape changes that already affect rural areas and might intensify in the future, this study explores how people who actually use the landscape for recreation evaluate future landscape changes in their favorite recreation area. Special focus has been put on landscape changes by dendromass cultivation for energy purposes. We conducted a survey in the Hamburg Metropolitan Region in Germany and asked urban dwellers to evaluate different landscape changes and their influence on recreational suitability. We wanted to evaluate how landscape character influences the evaluation of landscape changes. The main hypothesis is that landscape changes are evaluated differently depending on the individual character of each recre- ation area. Specifically, our research questions were:

- How do urban residents evaluate potential landscape changes in their preferred rural recreation areas?

- Does the evaluation of landscape changes depend on the landscape character of the recreation areas?

- How do urban residents evaluate the contribution of agriculture and forestry in maintaining the recreation areas and does the evaluation depend on the character of the landscape?

- Which implications on recreation has future land use such as short rotation coppice?

\section{Research design and methods}

A standardized quantitative survey was conducted in face-to-face interviews with citizens in different districts of Hamburg from February to April $2011(\mathrm{n}=400)$. The interviews lasted about 10-15 minutes and were supported by the use of answer selection cards which were shown to the respondents in order to improve understanding and rating. The answer selection cards included the rating scale to illustrate equal distances among rating categories. The survey was limited to citizens of the city of Hamburg and the directly adjacent urban districts because knowledge about the rural recreation areas around Hamburg was a prerequisite to assess landscape changes in the areas. The selection of respondents was random at first. Later, in a supplementary round of interviews, it was adjusted to increase underrepresented population groups in terms of age and gender in order to achieve improved representativeness for the Hamburg population (Dockerty et al. 2009). The sampling for the factors educational level and residential district was only influenced indirectly by choosing the location where people were interviewed. The response rate was about $30 \%$ (rate of addressed persons that took part in the survey), so all in all we addressed more than 1300 persons. The main reasons why people did not take part in the survey were lack of time and disinterest in a survey. The response rate may have influenced the representativeness of the sample; however, a general non-response bias is not assumed.

The survey focused on the southern part of the Hamburg Metropolitan Region in Lower Saxony and its important recreation areas Lüneburg Heath, Harburg Hills, Elbe Marshes and Altes Land. These four areas were chosen in advance as they are the most popular recreation areas used for landscape-related recreation in the southern Hamburg Metropolitan Region. They are, on the one hand, characteristic for the region and, on the other hand, differ strongly in terms of their landscape character and visual appearance. Each respondent only evaluated land- scape changes for his favorite recreation area. Consequently, the total sample of $\mathrm{n}=$ 400 was divided into four sub-samples depending on respondents' preference for the recreation areas $(n=138$ for the Lüneburg Heath, $\mathrm{n}=137$ for the Altes Land, $\mathrm{n}=75$ for the Elbe Marshes, $n=50$ for the Harburg Hills). This approach implies that sub-samples of people who prefer different recreation areas might be statistically different from the total sample. The limitation of one recreation area per respondent was chosen because this approach ensures that respondents really care about the landscape changes that are taking place in their favorite recreation area. Also pre-tests revealed that most people were not able to evaluate all four recreation areas. Since we only dealt with favorite recreation areas, respondents had a mental picture of the area and we did not have to use photographs to visualize landscape changes. We assume that each recreation area is sufficiently characteristic to have a consensus on the general appearance of the landscape among respondents. As we target the general appearance, minor differences between peoples' perception are negligible. We did not use visualizations because we wanted to compare evaluations throughout spatially defined recreation areas (landscape scale). The objective of the investigation was to grasp the reaction to changes to the landscape as an entity, as depicted in the minds of the respondents. This perception of a landscape may differ between the individuals. However, that is not relevant as long as the goal is to catch the collective reaction to changes. In contrast, visualizations would be useful for a more detailed analysis of changes in small areas.

Respondents were asked to evaluate different landscape changes in comparison to the current condition of their favorite recreation area. As landscape changes are mostly seen as negative in the first place (Lindenau 2002), we did not ask directly which landscape changes people would accept. Instead, we reversed the question to "Which landscape changes would negatively influence recreational suitability for you?". The answer categories for each landscape change were "decrease of recreational suitability" and "no decrease of recreational suitability". Landscape changes were formulated as neutrally as possible in order not to provoke emotional answers. The evaluated landscape changes address land use changes and changes in infrastructure and service facilities (Tab. 1).

We asked about landscape changes in both directions (e.g., "more hedges and shrubs" and "fewer hedges and shrubs") as a positive reaction towards more hedges and shrubs does not imply that fewer hedges and shrubs are evaluated negatively. The attitudes of respondents towards agriculture and forestry were surveyed by the question: "How do you 
evaluate the contributions of agriculture/ forestry in maintaining the recreation area?". Answers were recorded on a 5-point Likert scale from -2 to +2 (very negative/ negative/ neutral/ positive/ very positive).

We transferred the results from the evaluation of well-known and conceivable land use changes to novel, future landscape changes. We focused on landscape changes by dendromass cultivation for energy purposes in SRC. We used the evaluations of landscape changes concerning the forest/ open landscape ratio, more or less hedges and shrubs, more or less fields and assessments of agriculture and forestry to derive hypotheses about the potential impacts of dendromass cultivation in SRC on recreation. For example, if an increase of forests, hedges and shrubs was evaluated negatively in a certain landscape, we assumed that the introduction of SRC will also have negative implications on recreation in this landscape. If the evaluations of forests and hedges and shrubs were different in a certain landscape, we assume that the cultivation system of SRC will have a strong influence on their acceptability in this landscape. The other landscape changes concerning buildings, tourists, accessibility and services were surveyed to derive a reference framework for the evaluations of dendromass.

In addition to the survey questions, general information about each respondent was gathered, such as place of residence, age, gender and education. Survey responses were evaluated using the software SPSS ${ }^{\circledR}$ v. 19 Significance for evaluations of landscape changes was statistically analyzed by Pearson's chi-squared test. This test was used to analyze whether the evaluations of landscape changes are independent of the four recreation areas (test of independence). The null hypothesis was that evaluations of landscape changes are consistent among recreation areas. If Pearson's chi-squared test was significant, this meant that landscape changes were evaluated differently among recreation areas. The significance was measured on four levels - (n.s.): not significant, $p \geq 0.05$; $(*)$ : significant, $\mathrm{p}<0.05 ;(* *)$ : very significant, $\mathrm{p}<0.01 ;(* * *)$ : highly significant, $\mathrm{p}<$ 0.001 . Pearson's chi-squared test was also used to test the representativeness of the sample for the Hamburg population. Evaluations for agriculture and forestry on the fivelevel rating scale were analyzed using Kruskal-Wallis one-way analysis of variance. This test is the non-parametric equivalent of the one-way analysis of variance (ANOVA) and was used to analyze whether the assessments of agriculture and forestry were different among recreation areas. The mean assessments of agriculture and forestry were analyzed and compared by Wilcoxon signedrank test. Analyzed variables did not have to follow a normal distribution (Kolmogorov-

Tab. 1 - Surveyed landscape changes with explanation.

\begin{tabular}{|c|c|c|}
\hline Label & $\begin{array}{l}\text { Surveyed landscape } \\
\text { changes }\end{array}$ & Explanation/Influence on \\
\hline $\mathrm{a}$ & $\begin{array}{l}\text { more forests at the expense of } \\
\text { open land }\end{array}$ & \multirow[t]{2}{*}{$\begin{array}{l}\text { forest/open landscape ratio; openness of the } \\
\text { landscape }\end{array}$} \\
\hline $\mathrm{b}$ & $\begin{array}{l}\text { more open land at the expense } \\
\text { of forests }\end{array}$ & \\
\hline $\mathrm{c}$ & more hedges and shrubs & \multirow{2}{*}{$\begin{array}{l}\text { structural diversity; complexity of the visual } \\
\text { landscape }\end{array}$} \\
\hline $\mathrm{d}$ & fewer hedges and shrubs & \\
\hline $\mathrm{e}$ & $\begin{array}{l}\text { more fields at the expense of } \\
\text { meadows and pastures }\end{array}$ & \multirow[t]{2}{*}{ type of agriculture; intensity of agricultural use } \\
\hline $\mathrm{f}$ & $\begin{array}{l}\text { more meadows and pastures at } \\
\text { the expense of fields }\end{array}$ & \\
\hline g & less maintenance & $\begin{array}{l}\text { intensity of land use; general level of mainte- } \\
\text { nance or naturalness in the landscape; explained } \\
\text { to respondents by "less maintenance, rather leave } \\
\text { nature untouched" }\end{array}$ \\
\hline $\mathrm{h}$ & more buildings & construction of buildings \\
\hline $\mathrm{i}$ & more tourists & number of tourists in the recreation area \\
\hline j & lower accessibility & accessibility of the recreation area \\
\hline $\mathrm{k}$ & fewer services available & $\begin{array}{l}\text { service infrastructure; endowment with service } \\
\text { facilities }\end{array}$ \\
\hline
\end{tabular}

Smirnov test), as only non-parametric methods were used.

\section{Sample characteristics and representa- tiveness}

The sample for the Hamburg population was representative for age and gender, but not for education and residential district (based on comparisons with data from the Federal Statistical Office 2010 and the Statistical Office North 2009). About $90.5 \%$ of the respondents lived inside the city boundaries of Hamburg while $9.5 \%$ lived in urban districts directly adjacent to Hamburg. As the number of people living outside Hamburg was too low for statistical analysis, the whole sample was tested on representativeness for the Hamburg population. The representativeness for the factor residential district was only tested for respondents who live in Hamburg.

The male/ female ratio did not significantly deviate from the population of Hamburg $\left(\chi^{2}\right.$ $=0.057, \mathrm{df}=1, \mathrm{p}=0.812)$. The average age of the sample was 44 years $(\min =15$, $\max =$ 85), while the average age of the Hamburg population is 42.2 years (Statistical Office North 2009). The sample did not significantly deviate from the age distribution among age classes $(<30$ years $/ 30<50$ years/ $50<65$ years $/ \geq 65$ years) of the Hamburg population $\left(\chi^{2}=7.612, \mathrm{df}=3, \mathrm{p}=0.055\right)$. The educational level of the sample was significantly higher than that of the Hamburg population $\left(\chi^{2}=81.229\right.$, df $\left.=1, p<0.001\right)$. While the percentage of people with a general qualification for university entrance ("Abitur") was $67 \%$ in the sample, it is 44.6 $\%$ in the population of Hamburg. In terms of the residential district the sample was also not representative for Hamburg, as differen- ces between our sample and the statistical data for Hamburg were significant $\left(\chi^{2}=\right.$ 97.678, df $=6, \mathrm{p}<0.001)$.

\section{Evaluated recreation areas}

The recreation areas Lüneburg Heath, Harburg Hills, Elbe Marshes and Altes Land are characterized by specific land uses which form the individual landscape character of the area (Tab. 2). While the Lüneburg Heath, the Altes Land and in parts the Elbe Marshes are well-known historical cultural landscapes (Burggraaff \& Kleefeld 1998), the Harburg Hills are not of specific importance in terms of their cultural and natural heritage.

The Lüneburg Heath is an important tourist destination in northern Germany, which is famous for its specific landscape character and the heather blossom (Pott 1999). The sandy heathland and nutrient-poor grassland of the Lüneburg Heath are cultural landscapes, which were once created by clearing the original forests and over-grazing and burning the soils. Today they remain one of the largest heathlands in central Europe. The Harburg Hills are a hilly forest area with some farmland, which is located between the Lüneburg Heath and Hamburg (Fig. 1). They are directly south of the Hamburg city borders and are easily accessible by public transport. The Elbe River Marshes are located on both sides of the Elbe River and form its floodplain. These marshes have rich soils and are thus important for agriculture and at the same time for nature conservation. There is a high amount of meadows on the wet areas and fields on the drier parts (BfN 2012a). In the open landscape of the marshes the amount of forests is very low; however, several parts are characterized by small-scale agricultural land use and have a high land- 
Tab. 2 - Land uses in the recreation areas with the most characteristic land uses (*). (1): CORINE Land Cover classes 2006; (2): Landscape types defined by the German Federal Agency for Nature Conservation (BfN 2012b); (3): Protected areas include biosphere reserves, special areas of conservation, special protection areas, nature reserves and landscape reserves (BfN 2012c); (4): Assessment criteria for individual landscapes include naturalness, rarity, share of protected areas and fragmentation of the landscape (BfN 2012c).

\begin{tabular}{|c|c|c|c|c|}
\hline Land use $^{1}$ & Lüneburg Heath & Harburg Hills & Elbe Marshes & Altes Land \\
\hline Urban fabric & $2.0 \%$ & $8.6 \%$ & $6.1 \%$ & $8.7 \%$ \\
\hline Arable land & $12.3 \%$ & $27.5 \%$ & $36.8 \%$ & $2.8 \%$ \\
\hline Grassland & $4.8 \%$ & $2.9 \%$ & $29.3 \%{ }^{(*)}$ & $22.9 \%$ \\
\hline $\begin{array}{l}\text { Heterogeneous } \\
\text { agricultural areas }\end{array}$ & $6.2 \%$ & $7.9 \%$ & $10.1 \%$ & $1.0 \%$ \\
\hline Orchards & $0.0 \%$ & $0.0 \%$ & $0.6 \%$ & $64.0 \%{ }^{(*)}$ \\
\hline $\begin{array}{l}\text { Moors and } \\
\text { heathland }\end{array}$ & $20.6 \%{ }^{(*)}$ & $2.0 \%$ & $0.6 \%$ & $0.0 \%$ \\
\hline Water bodies & $0.2 \%$ & $0.0 \%$ & $4.1 \%{ }^{(*)}$ & $0.3 \%$ \\
\hline Forest & $53.8 \%$ & $51.1 \%^{(*)}$ & $12.5 \%$ & $0.3 \%$ \\
\hline Landscape type $^{2}$ & $\begin{array}{l}\text { forest landscape rich in } \\
\text { heath and nutrient-poor } \\
\text { grassland }\end{array}$ & forest landscape & $\begin{array}{c}\text { grassland-dominated } \\
\text { open cultural landscape/ } \\
\text { river landscape }\end{array}$ & orchard landscape \\
\hline $\begin{array}{l}\text { Share of } \\
\text { protected areas }\end{array}$ & $78.22 \%$ & $7.55 \%$ & $43.5 \%$ & $12.17 \%$ \\
\hline $\begin{array}{l}\text { Nature conservation } \\
\text { value }^{4}\end{array}$ & $\begin{array}{c}\text { landscape very worthy } \\
\text { of protection }\end{array}$ & $\begin{array}{c}\text { landscape of } \\
\text { low importance }\end{array}$ & $\begin{array}{l}\text { landscape with deficits } \\
\text { worthy of protection }\end{array}$ & $\begin{array}{l}\text { landscape with deficits } \\
\text { worthy of protection }\end{array}$ \\
\hline $\begin{array}{l}\text { Relevance for } \\
\text { recreation }\end{array}$ & $\begin{array}{l}\text { nationally and internationally } \\
\text { important tourist destination in } \\
\text { northern Germany, oldest and } \\
\text { largest nature reserve in Lower } \\
\text { Saxony }\end{array}$ & $\begin{array}{l}\text { first range of hills south } \\
\text { of Hamburg, popular local } \\
\text { forest recreation area } \\
\text { (e.g., walking, riding } \\
\text { mountain biking) }\end{array}$ & $\begin{array}{l}\text { belongs to the "Elbe Valley } \\
\text { Meadows" biosphere } \\
\text { reserve, of state and party } \\
\text { national importance, } \\
\text { popular tourist destination } \\
\text { (e.g., cycling) }\end{array}$ & $\begin{array}{l}\text { largest spatially coherent } \\
\text { fruit cultivation area of } \\
\text { Central Europe, } \\
\text { well-known and popular } \\
\text { cultural landscape }\end{array}$ \\
\hline
\end{tabular}

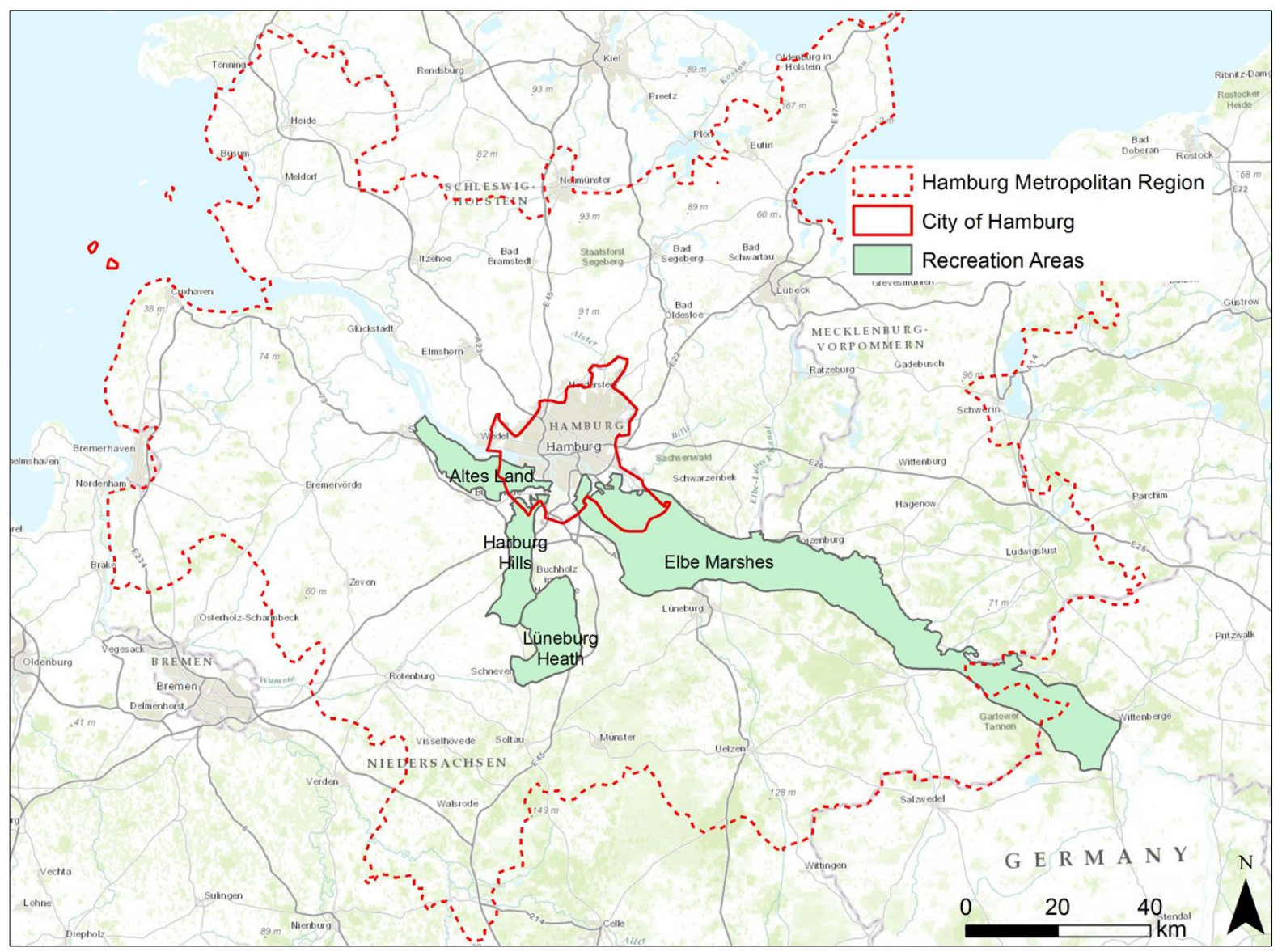

Fig. 1 - Location of the recreation areas in the Hamburg Metropolitan Region. 
scape diversity (i.e., rich in hedges). The Altes Land is famous for being one of the largest orchard areas in central Europe. It is an important tourist destination, especially during apple blossom in spring.

The most characteristic land uses of the recreation areas are highlighted in Tab. 2 These characteristic parts of the recreation areas are generally most frequently visited by tourists and recreationists. For example, people visit the Lüneburg Heath for the heathland, the Harburg Hills for the forests, the Elbe River Marshes for the meadows and open landscape and the Altes Land for the orchards.

\section{Results}

The results were first analyzed to evaluate generally accepted and rejected landscape changes across all recreation areas. Then, we analyzed landscape change evaluations for each recreation area separately. After this, the attitudes towards agriculture and forestry were first analyzed generally and then for each recreation area separately.

\section{Evaluation of landscape changes}

Although the recreation areas are generally valued for their current visual appearance, there was not an overall rejection of landscape changes. The evaluation of landscape changes showed huge variation; the rejection rates ranged from 11.8 to $97.2 \%$ (Fig. 2) Only four changes were generally rejected by the majority of all respondents (across all recreation areas). The highest rate of rejection was observed for the construction of buildings $(97.2 \%)$ and an increase of fields at the expense of meadows and pastures $(82.6 \%)$. Changes concerning more tourists

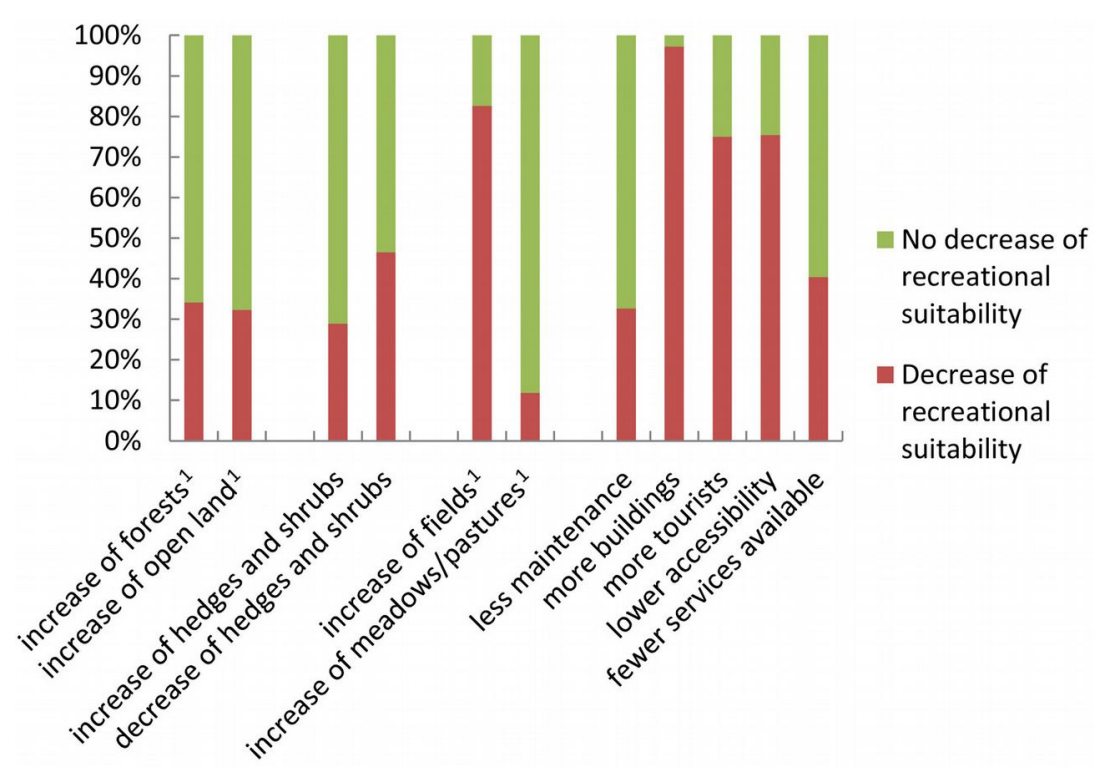

Fig. 2 - Evaluation of landscape changes across all recreation areas $(\mathrm{n}=339-392)$ : "Which changes would negatively influence recreational suitability for you?". (1): An increase of these land uses includes the decrease of the opposed land use, e.g., "increase of forests at the expense of open land".
(71.3\%) and lower accessibility of the recreation areas $(75 \%)$ were also widely rejected. Compared to these strongly rejected landscape changes, most land use changes, like increases and decreases of forests, hedges and shrubs generally had lower rejection rates.

In general, respondents were indifferent about the forest/ open landscape ratio. Only few people saw a decrease in recreational suitability by introducing more forests at the expense of open land $(34.1 \%$ of respondents), while the same was true for an increase of open land at the expense of forests $(32.3 \%)$. An increase of hedges and shrubs was regarded less negatively than an increase of forest. Relatively few people thought more hedges and shrubs would decrease recreational suitability $(28.9 \%)$, while there was stronger opposition against a decrease of hedges and shrubs (46.5\%). However, the values were moderate compared to landscape changes concerning fields versus meadows and pastures. An increase of fields at the expense of meadows and pastures decreased recreational suitability for $82.6 \%$ of respondents, while only $10.8 \%$ thought that more meadows and pastures at the expense of fields would decrease recreational suitability. Some $32.6 \%$ thought that less maintenance or less human influence decreases recreational suitability. Fewer on-site services decreased recreational suitability for $40.4 \%$ of respondents.

\section{Evaluation of landscape changes among recreation areas}

While some evaluations of landscape changes were significantly different among the recreation areas, others were not influenced

by the different landscape character of the recreation areas. Changes in the forest/open landscape ratio were evaluated most significantly different among recreation areas (Fig. 3 ). Changes, like an increase of hedges and shrubs, an increase of meadows and pastures at the expense of open land, less maintenance and more tourists were also evaluated significantly different, however not on the highest significance level. Changes like a decrease of hedges and shrubs, an increase of fields at the expense of meadows and pastures, more buildings, lower accessibility and fewer services were not evaluated significantly different; this means the evaluation of these changes was not influenced by the different landscape character of the recreation areas.

\section{More forests versus more open land}

An increase of forest at the expense of open land was evaluated significantly different among the recreation areas on the highest significance level $\left(\chi^{2}=22.088, \mathrm{df}=3\right.$, $\mathrm{p}<0.001$ - Fig. 3a). Respondents were more accepting of more forests for the Harburg Hills than for the other recreation areas. Although the Harburg Hills are already characterized by a high portion of forests, an increase of forests at the expense of open land was generally not evaluated negatively. Only $13.3 \%$ thought that more forests would decrease recreational suitability, which means that a vast majority $(86.7 \%)$ did not regard an increase of forests negatively. An increase of forests was not assessed as positively for the recreation areas that are characterized by open landscapes, like the Lüneburg Heath (heathlands) and the Elbe Marshes (meadows and wetlands), where the rejection rate of forests was similar: $44.7 \%$ of respondents thought that an increase of forests would decrease recreational suitability for the Lüneburg Heath and $43.5 \%$ for the Elbe Marshes. The orchard landscape of the Altes Land was evaluated in between with $25.6 \%$ of respondents answering that an increase of forest would decrease recreational suitability. An increase of open land at the expense of forest was also evaluated significantly different among the recreation areas on the highest significance level $\left(\chi^{2}=22.236, \mathrm{df}=3\right.$, $p<0.001$ - Fig. 3b). However, only for the Harburg Hills did the majority of respondents say that an increase of open land would decrease recreational suitability $(62.2$ $\%$ ), while the results for the other recreation areas were similar $(24.6 \%$ for Altes Land, $29 \%$ for Elbe Marshes and $31.3 \%$ for Lüneburg Heath). Likewise, the Lüneburg Heath and the Elbe Marshes showed similar results; an increase of forests was evaluated relatively negative, while an increase of open land was regarded relatively positive. For the Harburg Hills, on the contrary, an increase of forests was evaluated relatively positive, 
(a) Increase of forests at the expense

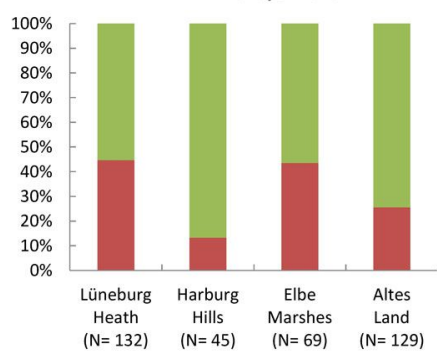

(d) Decrease of hedges and shrubs n.s.

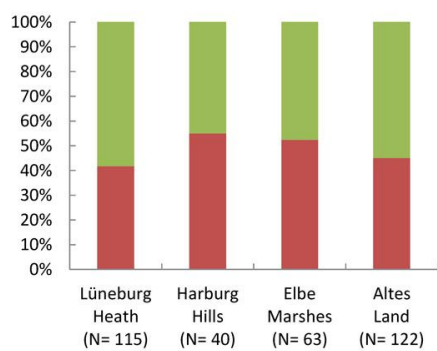

(g) Less
maintenance

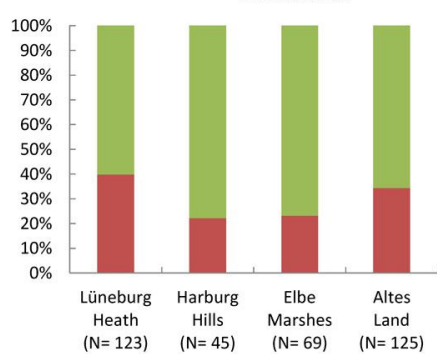

(j) Lower accessibility

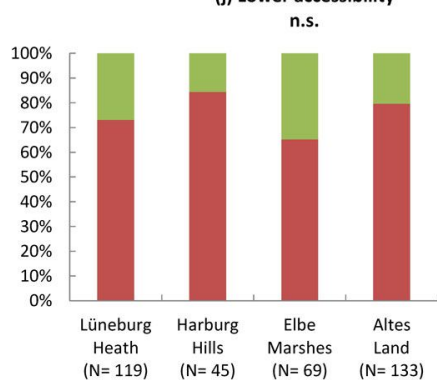

(b) Increase of open land at the expense of forests $* * *$
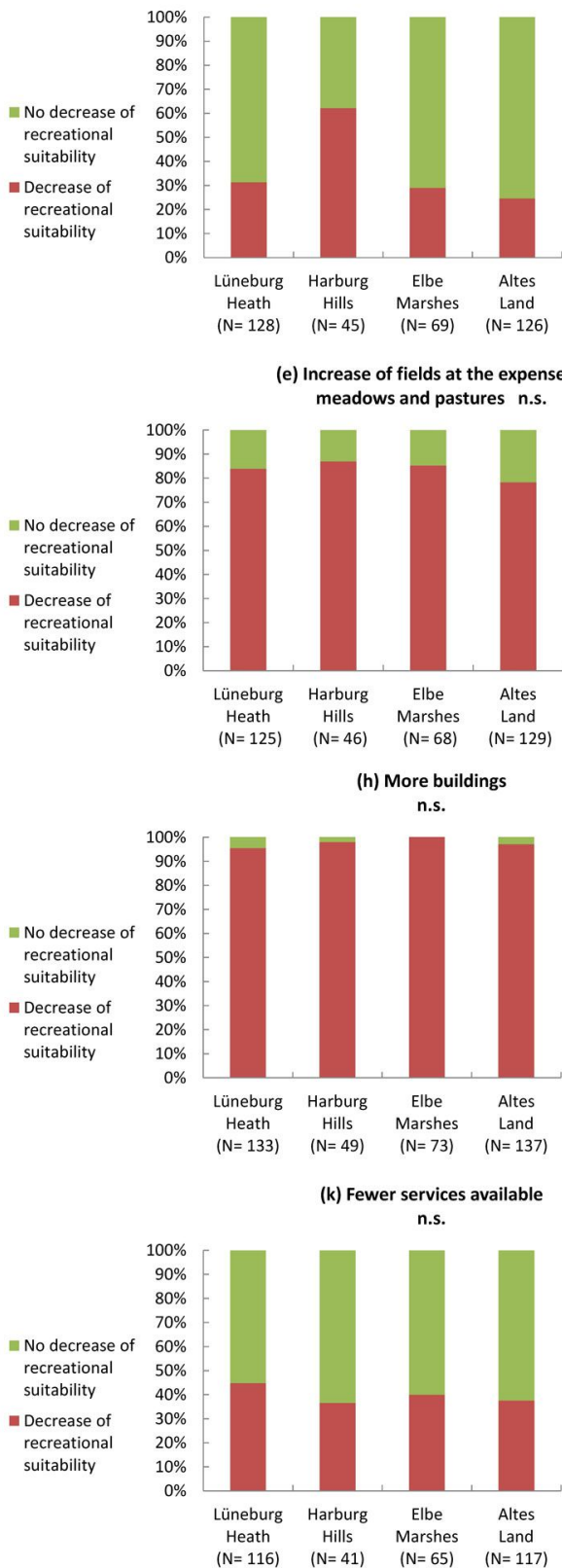
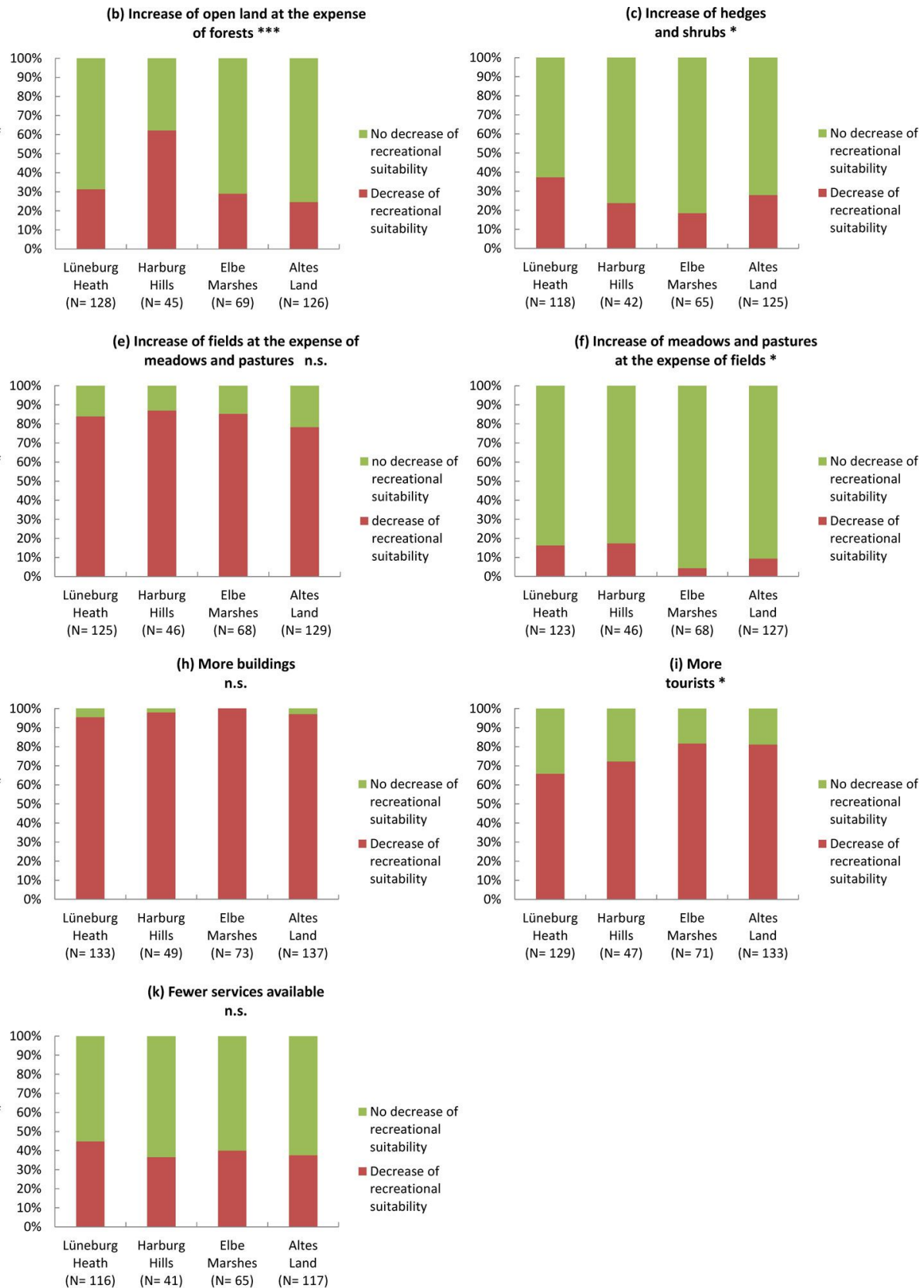

Fig. 3 - Differences of evaluations of landscape changes among recreation areas. $(*)$ : significant $(\mathrm{p}<0.05)$; $(* *)$ : very significant $(\mathrm{p}<0.01)$; $(* * *)$ : highly significant $(\mathrm{p}<0.001)$; (n.s.): not significant $(\mathrm{p} \geq 0.05)$.

while an increase of open land was regarded relatively negative. For the Altes Land both an increase of forests and an increase of open land did not face strong opposition. As the height of the espalier fruit trees is between open land and forest, a change towards more forests or more open land would not have such a great influence on the visual landscape.

\section{More hedges and shrubs versus fewer hedges and shrubs}

Landscape changes concerning more hedges and shrubs were evaluated significantly different among the recreation areas, although not on the highest significance level like landscape changes concerning forest and open land $\left(\chi^{2}=8.073, \mathrm{df}=3, \mathrm{p}=0.045\right.$ - Fig. $3 c)$. For the Elbe Marshes very few people $(18.5 \%)$ thought that more hedges and shrubs would negatively influence recreation, while for the Lüneburg Heath more people thought they would negatively affect recreation $(37.3 \%)$. This shows that the recreation areas Lüneburg Heath and Elbe Marshes, which are both characterized by open landscapes, were evaluated differently for some changes concerning woody struc- tures. While a change in the forest/open landscape ratio was assessed similarly, an increase of hedges and shrubs was evaluated differently depending on the type of open landscape (heathland or meadows and pastures). A decrease of hedges and shrubs was not evaluated significantly different among the recreation areas $\left(\chi^{2}=3.184\right.$, $\mathrm{df}=3, \mathrm{p}=$ 0.364 - Fig. 3d). It was evaluated relatively negative for all recreation areas; however, some differences should be mentioned. For the areas, where an increase of hedges and shrubs was evaluated relatively negative, a decrease caused relatively little opposition 
(Lüneburg Heath $41.7 \%$ and Altes Land $45.1 \%)$. For the Harburg Hills (55\%) and for the Elbe Marshes (52.4\%) the majority rejected a decrease of hedges and shrubs.

\section{More fields versus more meadows and pas-} tures

The evaluation of an increase of fields at the expense of meadows and pastures was very negative for all recreation areas and therefore not significantly different among the areas $\left(\chi^{2}=2.786, \mathrm{df}=3, \mathrm{p}=0.426\right.$ - Fig. $3 \mathrm{e})$. The share of people that considered an increase of fields as a decrease of recreational suitability ranges from $78.3 \%$ for the Altes Land, $84 \%$ for the Lüneburg Heath, $85.3 \%$ for the Elbe Marshes to $87 \%$ for the Harburg Hills. The evaluation of an increase of meadows and pastures at the expense of fields was significantly different on the 0.5 level $\left(\chi^{2}=7.966, d f=3, p=0.047\right.$ - Fig. 3f). For the Lüneburg Heath and the Harburg Hills, where meadows are not very common (Tab. 2), more people thought an increase of meadows and pastures would negatively influence recreational suitability $(16.3 \%$ for the Lüneburg Heath, $17.4 \%$ for the Harburg Hills) than for the areas where meadows are frequent (4.4\% for the Elbe Marshes, $9.4 \%$ for the Altes Land).

\section{Less maintenance, more buildings, more} tourists, lower accessibility and fewer services

Less maintenance or less human influence in the recreation areas was not seen as a decrease of recreational suitability by the majority of respondents; however, results were significantly different among recreation areas $\left(\chi^{2}=8.104, d f=3, p=0.044\right.$ - Fig. $\left.3 g\right)$. Taking the characteristic land uses in the recreation areas into account, more respondents thought less maintenance in the already extensively used heathland of the Lüneburg Heath would be negative for recreation (39.8\%), but also in the intensively used orchards of the Altes Land (34.4\%). On the contrary, significantly fewer respondents considered that less maintenance in the forests of the Harburg Hills (22.2 \%) and the meadows and pastures of the Elbe Marshes $(23.2 \%)$ would decrease recreational suitability.

The construction of more buildings was evaluated very negatively for all recreation areas and was not significantly different among the areas $(97.2 \%$ average disapproval rate across all recreation areas; $\chi^{2}=$ 3.637 , df $=3, p=0.303$ - Fig. 3h). More tourists also detracted from recreation for most respondents. However, an increase of tourists was evaluated significantly different among the recreation areas $\left(\chi^{2}=10.309, \mathrm{df}=\right.$ $3, p=0.016$ - Fig. 3i). While for the Elbe Marshes and for the Altes Land an increase of tourists was seen as negative by many

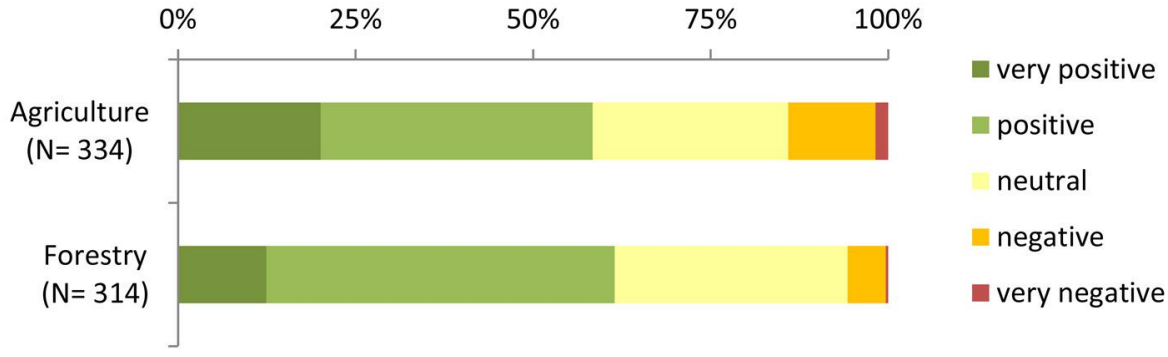

Fig. 4 - Evaluation of agriculture and forestry: "How do you assess the role of agriculture/ forestry in maintaining the recreation area?".

people $(81.7 \%$ and $81.2 \%$, respectively), for the Lüneburg Heath less people regarded an increase of tourists negatively $(65.9 \%)$. The evaluation for the Harburg Hills was in between $(72.3 \%)$. Interestingly, the most popular and most visited recreation areas Lüneburg Heath and Altes Land were evaluated significantly different. The same was true for the Harburg Hills and the Elbe Marshes which are not as famous and do not have comparable high tourist numbers. Lower accessibility of the recreation areas was not evaluated significantly different among recreation areas $\left(\chi^{2}=7.506, \mathrm{df}=3, \mathrm{p}=\right.$ 0.057 - Fig. 3j). For the Harburg Hills and the Altes Land, which are both easily accessible by public transport from Hamburg,

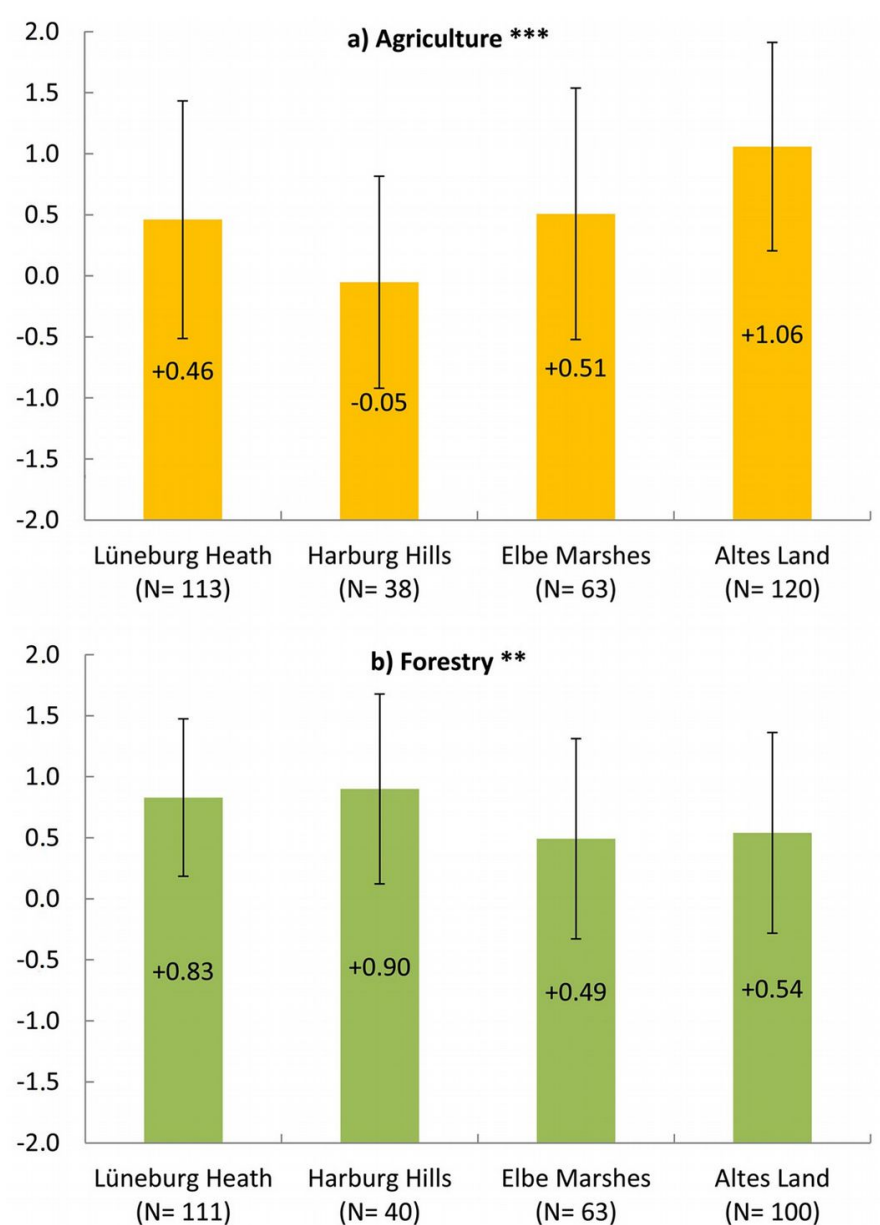

lower accessibility was evaluated as a decrease of recreational suitability by $84.4 \%$ and $79.7 \%$, respectively. For the Lüneburg Heath and the Elbe Marshes, which are further away from Hamburg or not easily accessible by public transport, only $73.1 \%$ and $65.2 \%$, respectively, assessed lower accessibility negatively. Less services available was not a big concern for respondents for all recreation areas compared to an increase of tourists and more buildings. The differences among the recreation areas were not significant $\left(\chi^{2}=1.575, \mathrm{df}=3, \mathrm{p}=0.665\right.$ - Fig. $\left.3 \mathrm{k}\right)$. For the Lüneburg Heath respondents saw a slightly higher negative impact on recreation if fewer services are offered $(44.8 \%$ compared to $36.6 \%$ for the Harburg Hills, 37.6
Fig. 5 - Differences of mean assessment of agriculture and forestry among recreation areas. $(* *)$ : very significant $(\mathrm{p}<0.01) ;(* * *)$ : highly significant $(p<0.001)$. 
Tab. 3 - Importance to consider the landscape type for different landscape changes. The as sessment of the importance to consider the landscape type for different landscape changes is directly related to the test of significance (Fig. 3, e.g., highly significant different evaluation of a landscape change among recreation areas $=$ very important to consider the landscape type when dealing with this landscape change).

\begin{tabular}{lc}
\hline Landscape change & $\begin{array}{l}\text { Importance to consider } \\
\text { the landscape type }\end{array}$ \\
\hline increase of forests at the expense of open land & very important $/ * * *$ \\
increase of open land at the expense of forests & very important $/ * * *$ \\
increase of hedges and shrubs & quite important $/ *$ \\
decrease of hedges and shrubs & not important /n.s. \\
increase of fields at the expense of meadows and pastures & not important / n.s. \\
increase of meadows and pastures at the expense of fields & quite important /* \\
less maintenance & quite important $/ *$ \\
more buildings & not important /n.s. \\
more tourists & quite important $/ *$ \\
lower accessibility & not important /n.s. \\
fewer services available & not important /n.s. \\
\hline
\end{tabular}

$\%$ for the Altes Land and $40 \%$ for the Elbe Marshes).

\section{Evaluation of agriculture and forestry}

Most people thought that agriculture and forestry contribute positively to maintaining the recreation areas. Some $58.4 \%$ of respondents considered agriculture as positive or very positive and $61.5 \%$ thought so of forestry (Fig. 4). There were no significant differences between median values of the evaluation of agriculture and forestry (Wilcoxon signed rank test: $p=0.415$ ). Although median values did not differ significantly, the frequency distribution of the assessment of agriculture and forestry differed significantly $\left(\chi^{2}=116.463, \mathrm{df}=16, \mathrm{p}>0.001\right)$. The assessment of agriculture showed more extreme values (very positive and very negative) in comparison to forestry which was evaluated more moderately. While only 5.7 $\%$ of respondents thought that the role of forestry in maintaining the recreation areas is negative or very negative, $14.1 \%$ thought so of agriculture. On the other hand, there were significantly more respondents who assessed agriculture as very positive. While $20.1 \%$ of respondents considered the role of agriculture as very positive, only $12.4 \%$ of respondents thought so of forestry. Differences in variation were highlighted by the different standard deviations $(0.996$ for agriculture 0.772 for forestry). There was a significant correlation between the assessment of agriculture and forestry $\left(r_{\mathrm{S}}=0.213, \mathrm{p}<0.001,2\right.$ sided) which means that people with a positive attitude towards agriculture were likely to have a positive attitude towards forestry as well.

\section{Evaluation of agriculture and forestry among recreation areas}

Both agriculture and forestry were assessed significantly different among the recreation areas (Kruskal-Wallis one-way analysis of variance: $p<0.001$ for agriculture, $p<0.01$ for forestry). For the Harburg Hills agriculture was assessed more negatively than for the other areas with the only mean assessment that was negative $(-0.05$ on the -2 to +2 scale - Fig. 5). For the Altes Land agriculture was assessed the most positively $(+1.06)$, while the assessment of agriculture was moderate for the Lüneburg Heath $(+0.46)$ and for the Elbe Marshes $(+0.51)$. Forestry was assessed more positively for the Lüneburg Heath $(+0.83)$ and Harburg Hills $(+0.90)$ where forestry is an important land use, while it was assessed moderately for the Elbe Marshes $(+0.49)$ and Altes Land $(+0.54)$ where forestry is not an important land use.

\section{Socio-demographic influence on the evaluation}

There were some differences among the sub-samples or groups of people that preferred different recreation areas. For example the sub-sample that favored the Elbe Marshes was significantly older than people who favored the Harburg Hills (ANOVA: $p=$ $0.014)$. The influence of other demographic factors was not significantly different between sub-samples.

There was no consistent influence of sociodemographic factors on the evaluation of landscape changes. While the factors educational level and gender were mostly not significant, the factor age had, in some cases, influence on the assessment of landscape changes. Older people evaluated an increase of forests significantly more negatively than young people $\left(\chi^{2}=7.887, \mathrm{df}=3, \mathrm{p}=0.048\right)$. Interestingly, an increase of hedges and shrubs was evaluated significantly more negative by young people $\left(\chi^{2}=8.265, \mathrm{df}=3, \mathrm{p}\right.$ $=0.041)$. Accordingly, a decrease of hedges and shrubs was evaluated significantly more negative by old people $\left(\chi^{2}=10.542, \mathrm{df}=3\right.$, $p=0.014)$. On the contrary, an increase of open land was not evaluated significantly different among age groups. Older people evaluated an increase of tourists significantly more positive than young people $\left(\chi^{2}=9.616\right.$, $\mathrm{df}=3, \mathrm{p}=0.022)$. All other evaluations of landscape changes did not differ among age groups.

\section{Discussion}

Our study found that many land use changes were viewed differently depending on the individual landscape character of each recreation area. The evaluations of landscape changes allow recommendations to be made on how to deal with landscape changes in planning processes. The more different a certain landscape change is evaluated among the recreation areas, the more important it is to consider the landscape type in the planning for such change (Tab. 3). For example it is very important to consider the landscape type when dealing with changes of the forest/ open landscape ratio, while it is quite important to consider the landscape type when more hedges and shrubs are introduced. On the contrary, it is not important to consider the landscape type when removing hedges and shrubs as these changes are evaluated the same among recreation areas, which is relatively negative in this case.

Of all evaluated types of landscape changes, modifications in the forest/ open landscape ratio were perceived most significantly different among landscapes. Conversely, this means that the landscape character is strongly depending on the forest/ open landscape ratio. Compared to other landscape changes, it is highly important to consider the landscape type when increasing or decreasing the forest share. Interestingly, the introduction of hedges and shrubs was evaluated very differently from the introduction of forests for some recreation areas. This means that respondents differentiated between types of woody structures, depending on the landscape type. For the Lüneburg Heath both an increase of forests and an increase of hedges and shrubs were evaluated relatively negative. For the other recreation areas, either an increase of forests or an increase of hedges and shrubs was evaluated more positively. Although for the Elbe Marshes, for example, an increase of forests was evaluated quite negatively, an increase of hedges and shrubs was evaluated most positively among all recreation areas. These results may be explained by the different landscape character of the Elbe Marshes and the Lüneburg Heath in terms of landscape structures. In the Elbe Marshes linear structures like hedges and tree rows around fields, meadows and pastures are very common and contribute strongly to the landscape character, while in the Lüneburg Heath almost no hedges exist. Therefore, an increase of hedges and shrubs would contribute to the particular landscape charac- 
ter of the Elbe Marshes, while it would change the landscape character of the Lüneburg Heath. The more the character of a landscape is changed, the more likely it is that the proposed landscape change will negatively affect the areas' attractiveness for recreationists and tourists.

It is not possible to directly transfer the results of the evaluation of forests, hedges and shrubs to the cultivation of SRC. We expect that the evaluation of an increase of SRC would be more negative than the evaluation of an increase of forests, hedges and shrubs, but more positive than the evaluation of an increase of fields. Mainly, we expect that the implications of SRC on the visual landscape will be different depending on the landscape and on the form of cultivation. Transferred to SRC, the results of this survey for forests could be similar to SRC plantations covering the whole field, and the results for hedges could be similar to SRC planted in strips. For the recreation areas in the Hamburg Metropolitan Region this would mean that SRC in strips would be most preferable for the Elbe Marshes, SRC covering the whole field for the Harburg Hills, no cultivation of SRC for the Lüneburg Heath and no preference for a specific cultivation method for the Altes Land.

As SRC is a cropping system between agriculture and forestry, it is important to consider the current perception of agriculture and forestry in future cultivation areas. In areas like the Altes Land, where the current agricultural practice was evaluated positively, it might be problematic to introduce a new system like SRC. In areas like the Harburg Hills, where the current agricultural practice was evaluated quite negatively, SRC could have positive impacts on the overall perception of agriculture. The general as sessment of agriculture and forestry seems to be dependent on the role which they play in the recreation areas. For the considered recreation areas people rated agricultural and silvicultural land use in general rather positive, but fields negatively. In the Altes Land, agriculture is the most important land use, and therefore, plays a major role in shaping the visual landscape. It is responsible for the unique character of the orchard landscape, which recreationists appreciate. On the other hand, agriculture is not very prevalent in the Harburg Hills. The role of agriculture in shaping the visual landscape is not very important, which might explain the negative assessment of agriculture in the Harburg Hills Agriculture in the Lüneburg Heath and in the Elbe Marshes was assessed moderately positive. In both recreation areas, agricultural land use is less intensive and diverse in the most characteristic parts of the heathland and the meadows and pastures. The Lüneburg Heath and the Elbe Marshes comprise many landscape and nature reserves (Tab. 2), which are managed with regard to conservation requirements. Obviously, people were aware of this farmland having a different character than in intensively farmed areas and mainly have a positive opinion about it. As the question was quite broad, it was not possible to differentiate between the preferred intensity and preferred spatial extent of agriculture and forestry. However, the positive evaluation of the intensive orchard landscape in the Altes Land shows that people do not prefer less intensive agriculture in all cases. Nevertheless, the orchards in the Altes Land are a rather special type of agriculture. It may be that people perceive it as rather natural or are attached to this landscape as it has been characteristic for the Hamburg Region since historic times. We assume that the rating of agriculture would be much more negative in an intensively farmed landscape with annual crops (Lindemann-Matthies et al. 2010).

The negative evaluation of more fields at the expense of meadows and pastures shows that people do not want an expansion and intensification of agriculture, which is currently taking place in many parts of the Hamburg Metropolitan Region, often due to the cultivation of bioenergy crops. People prefer less intensive agriculture such as meadows and pastures. SRC as a very extensive perennial agricultural system could therefore be perceived positively, especially when compared to other bioenergy crops that require intensive farming such as maize. The negative evaluation of fields is also supported by other surveys. According to a survey among 455 people by Kühne (2006), both forests and meadows are indispensable parts of the landscape, while fields are not mentioned by the respondents. However, surveys using visualizations on the street level perspective confirm positive influences of fields on the visual landscape if they are part of a diverse landscape (Hendriks et al. 2000). Schüpbach et al. (2009) found that the impacts of fields on the visual landscape differ strongly depending on the type of agricultural crop and the intensity of agricultural land use. Across all recreation areas only few people thought that less maintenance would negatively influence recreational suitability. The fact that less maintenance was evaluated most negatively for the Lüneburg Heath shows that people are aware of human influence on the landscape in general and on the heathland of the Lüneburg Heath in particular. Less maintenance in the Lüneburg Heath, for example, would result in the heathland being overgrown by shrubs and bushes in the course of time, while less maintenance in the Altes Land is not compatible with the intensively cultivated orchard landscape. On the contrary, less maintenance was welcomed by relatively many people in the Harburg Hills and the Elbe Marshes. This would result in more natural forests in the Harburg Hills and less intensive agriculture on the meadows and pastures of the Elbe Marshes.

The preferred recreation areas Lüneburg Heath and Altes Land are generally not more sensitive towards landscape changes than the less preferred areas Elbe Marshes and Harburg Hills. Thus, there is no recreation area where landscape changes are generally more accepted. This seems to refute the hypothesis, that only favored landscapes with a high symbolic and recreational value are highly sensitive to changes. However, all considered recreational landscapes have a high aesthetic value in comparison to non-recreational landscapes. Therefore, this hypothesis might be applicable on a broader level when also considering standard and everyday landscapes, which we assume to be less sensitive towards landscape changes. In general, we assume that land use changes are best accepted for intensively farmed agricultural landscapes, rather than for recreation areas with a high scenic value.

The limitations of this methodology and the specific conditions of the survey in the case examined here have to be considered when generalizing the results. We are aware of the drawbacks of comparing different subsamples. However, we only chose statistical tests that allow comparison of different sized sub-samples (Pearson's chi-squared test). We think it is possible to compare the sub-samples as statistical differences of respondents' characteristics among sub-samples were minor and did not significantly influence the evaluation of landscape changes. As the survey was on a large spatial level and asked about landscape changes for whole recreation areas, it was only possible to evaluate landscape changes that were easily imaginable. According to the definition of space and place by Tuan (1977), the space of the recreation areas is a place linked with cultural values and social meanings for the respondents. Therefore, the "mental picture" of respondents used in this study is highly subjective and includes personal associations and experiences with the recreation areas. Thus, the mental pictures should be validated by visualizing certain scenarios of landscape changes and transferring the results to smaller spatial levels. In the scope of this study it was not possible to do both; however, it would be interesting to compare the mental picture with visualizations of landscape changes in a follow-up study. The respondents were not directly asked about the cultivation of bioenergy crops to avoid strategic responses. As the focus of the study addressed the appearance of the visual landscape, answers should not be influenced by general attitudes towards bioenergy crops. This is why the results can only give a broad estimation on the overall acceptability of SRC. Furthermore, we only asked urban 
dwellers about their recreational preferences. Therefore, potentially different preferences of local inhabitants, farmers and foresters who use different ecosystem services have to be considered when it comes to planning decisions for the recreation areas.

\section{Results in the broader context}

Many studies have tried to identify an optimal landscape, which is best suited for human well-being. According to Appleton's prospect-refuge theory, this optimum landscape is savanna-like, characterized by its half-openness and a forest share of about 40 \% (Appleton 1975, Balling \& Falk 1982, U1rich 1986). Additionally, this survey shows that people prefer diversity among landscapes. As soon as we do not deal with an abstract landscape, but with places that people know, preferences differ between landscapes. Preferences for specific, known and favored places are, therefore, different from standard landscape preferences as these landscapes are also valued for their specific landscape character. Another reason is that knowledge of favored areas is higher and, therefore, landscape preferences can be more complex. The different assessments of landscape changes among recreation areas show that people are aware of the uniqueness of each area and would like to retain this uniqueness. In the end, people prefer a variety of different landscapes for their recreation which are characterized by particularity and uniqueness. Also, familiarity may play an important role. If people know a landscape well they evaluate landscape changes differently than people who are not familiar with the landscape (Hunziker et al. 2008).

The results of this study also show that recreationists are not per se against landscape changes in recreation areas. They are rather open towards changes, which do not directly compromise the specific character of the landscape. As to the question of an optimal landscape and criteria for measuring landscape visual quality, these findings stress the importance of the criterion uniqueness in the triad of landscape aesthetic criteria (diversity, naturalness and uniqueness) used for describing the expected general perception of the visual quality of a landscape (Köhler $\&$ Preiss 2000). However, we cannot draw from the findings benchmarks or thresholds, which might frame the importance of uniqueness. Such benchmarks refer to a minimum or maximum diversity in the landscape, the acceptable shares of different land uses (e.g., forests) or to the degree of naturalness (in terms of visible land use influence).

Other surveys show the importance of protecting cultural historical landscapes. In a study by the German Federal Ministry for Environment, Nature Conservation and $\mathrm{Nu}-$ clear Safety, $95 \%$ of the interviewees confirmed that "the beauty and characteristic features of our homeland should be conserved and protected" (BMU 2008), which is the highest endorsement compared to other environmentally-related statements, for example about sustainability and fair trade. This shows that landscape aesthetics and emotional bonds towards landscapes are of great importance for people and that beautiful and characteristic landscapes should be protected. These results support the findings of this survey that people prefer individual and characteristic landscapes and features rather than uniformly optimized landscapes.

Other regions in Europe also face landscape changes that might negatively influence landscape perception of tourists and the general public. Hunziker et al. (2008) found that people prefer the status quo of Swiss alpine landscapes compared to scenarios with increased and decreased amounts of hedges, shrubs and forests. However, there are strong differences between various population groups. The results for alpine landscapes show that there may also be large differences in the preference of recreationists, local inhabitants and other social groups in the Hamburg Metropolitan Region.

Generally stated, the results can be taken as a substantial and well founded hypothesis for other recreation areas of a similar landscape type and in a similar cultural context. For other quite different landscape types, for example mountainous regions, this methodology can be used to generate additional survey results.

\section{Conclusions}

In summary, our results show that:

- The majority of urban dwellers consider agricultural and silvicultural land use in recreation landscapes to have a positive impact on the visual landscape.

- Meadows and pastures are much more appreciated than fields; an intensification of agriculture by an increase of fields at the expense of meadows and pastures has therefore very negative impacts on the visual landscape.

- In most areas less maintenance is not considered negative for recreation.

- Most people do not think an increase of forests, hedges and shrubs would negatively influence recreational suitability.

However:

- The landscape character significantly influences whether a landscape change is accepted or rejected.

- Of all evaluated types of landscape changes, modifications in the forest/ open landscape ratio are perceived most significantly different among landscapes.

- We did not find a recreation landscape where landscape changes are more accepted in general; the acceptability always depends on the landscape type in connection with the type of change.
The results show that people are aware of different landscape types and do not want standard landscapes. The uniqueness of recreation areas is very important for recreation. This is why people accept landscape changes which enhance or do not affect the specific landscape character and which contribute to the uniqueness of the landscape. On the other hand, people dislike landscape changes that compromise the specific landscape character. Therefore, it is not possible to identify a landscape with optimal recreational suitability. People generally appreciate the differences among landscapes. That is why from the recreational point of view a strict protection of the status quo of historical cultural landscapes is not necessary.

Although agriculture and forestry are considered to have a positive influence on the recreation areas, people prefer less intensive agriculture. That is why further land use pressures by intensive energy crop cultivation could have negative influences on recreation landscapes. The cultivation of dendromass in SRC or agroforestry systems could be a compromise between agriculture and tourism in areas with high visual and recreational value. That is because fields are largely disliked by recreationists, but woody structures do not face strong opposition. In terms of bioenergy production, SRC could be more positive for the visual and recreational landscape than bioenergy maize, which is currently the most common crop. However, differences among landscapes and the different visual impacts of SRC, which depend on the cultivation system, have to be considered when cultivating SRC. We expect that implications of SRC on the visual landscape will be different depending on the landscape and on the form of cultivation, for example, for some landscapes forest-like structures are preferred and for others hedge-like structures. In order to improve the acceptance of agricultural practice and SRC in recreational landscapes, we recommend that the landscape character and the different sensitivities of landscapes are considered in the assessment of potential production sites.

\section{Acknowledgements}

TB developed the survey design, carried out the statistical analysis of the data and the writing of the paper. $\mathrm{CvH}$ and $\mathrm{CA}$ helped to draft the manuscript. Eick von Ruschkowski and Roswitha Kirsch-Stracke helped to develop the methods. The survey was supported by Janika Schemmel and Gerrit Schulz. Martha Graf helped to answer statistical questions and proof read the manuscript, as did Barty Warren-Kretzschmar.

The research is part of the project AgroForNet which is funded by the German Federal Ministry of Education and Research. AgroForNet will develop regional value creation networks for the sustainable and efficient 
production and supply of dendromass from agriculture, forestry and the open landscape. More information on AgroForNet is available on the German-language website http:// www.agrofornet.de.

\section{References}

Antrop M (2004). Landscape change and the urbanization process in Europe. Landscape and Urban Planning 67 (1-4): 9-26. - doi: 10.1016/S01 69-2046(03)00026-4

Appleton J (1975). The experience of landscape. Wiley, London, UK, pp. 296.

Balling JD, Falk JH (1982). Development of visual preference for natural environments. Environment and Behavior 14 (1): 5-28. - doi: 10.117 7/0013916582141001

Baum C, Leinweber P, Weih M, Lamersdorf N, Dimitriou I (2009). Effects of short rotation coppice with willows and poplar on soil ecology. Landbauforschung vTI Agriculture and Forestry Research 3 (59): 183-196. [online] URL: http:// www.bfafh.de/bibl/lbf-pdf/lbf-dl.htm

Bemmann A (2010). AGROWOOD. Kurzumtriebsplantagen in Deutschland und Europäische perspektiven [AGROWOOD. Short rotation coppice in Germany and European perspectives] Weißensee-Verlag (Ökologie), Berlin, Germany, pp. 342. [in German]

BfN (2012a). Landschaftssteckbriefe [Landscape characteristics]. German Federal Agency for Nature Conservation, web site. [in German] [online] URL: http://www.bfn.de/0311 landschaft en.html

BfN (2012b). Landschaftstypen [Landscape types]. German Federal Agency for Nature Conservation, web site. [in German] [online] URL: http://www.bfn.de/0311 landschaftstypen.html

BfN (2012c). Schutzwürdige Landschaften [Landscapes deserving protection]. German Federal Agency for Nature Conservation, web site. [in German] [online] URL: http://www.bfn.de/0311 schutzw_landsch.html

BMU (2008). Umweltbewusstsein in Deutschland Ergebnisse einer repräsentativen Bevölkerungsumfrage [Environmental awareness in Germany. Results of a representative public survey]. German Federal Ministry for Environment, Nature Conservation and Nuclear Safety, pp. 62. [in German] [online] URL: http://www.umweltbundesamt.de/sites/default/files/medien/publikation/ long/3678.pdf

Burggraaff P, Kleefeld KD (1998). Historische Kulturlandschaft und Kulturlandschaftselemente Teil I. Bundesübersicht. Teil II: Leitfaden [Historical cultural landscapes and cultural landscape elements]. Angewandte Landschaftsökologie 20, Bonn-Bad Godesberg, Germany, pp. 320. [in German]

Dockerty T, Lovett A, Appleton K, Sünnenberg G (2009). Public attitudes to biomass energy crops and their visual impacts. RELU biomass subproject report. University of East Anglia, Norwich, UK pp. 84. [online] URL: http://www.es ds.ac.uk/doc/6615/mrdoc/pdf/6615uguide.pdf European Commission (2007). Growing regions, growing Europe. Fourth report on economic and social cohesion, Office for Official Publications, European Communities, Luxembourg, pp. 200.

Federal Statistical Office (2010). Destatis regional atlas. Joint product by the statistical offices of the Federation and the Länder, Web site. [online] URL: https://www.destatis.de/onlineatlas

Franke U (2008). Thema: Landschaftsbild. Landschaft lesen. Impulse zur Landschaftsästhetik, Naturwahrnehmung und Landschaftsbildbewertung für die norddeutsche Kulturlandschaft [Topic: Visual Landscape. Reading Landscape. Impulses for landscape aesthetics, perception of nature and landscape character assessment for the northern German cultural landscape]. Oceano, Schwerin, Germany, pp. 94. [in German] [online] URL: http://www.ink-landschaft.de/index.php

Hendriks K, Stobbelaar DJ, van Mansvelt JD (2000). The appearance of agriculture: an assessment of the quality of landscape of both organic and conventional horticultural farms in West Friesland. Agriculture, Ecosystems and Environment 77 (1-2): 157-175. - doi: 10.1016/S01678809(99)00100-0

Hunziker M, Felber P, Gehring K, Buchecker M, Bauer N, Kienast F (2008). Evaluation of landscape change by different social groups. Results of two empirical studies in Switzerland. Mountain Research and Development 28: 140-147. doi: 10.1659/mrd.0952

Köhler B, Preiss A (2000). Erfassung und Bewertung des Landschaftsbildes. Grundlagen und Methoden zur Bearbeitung des Schutzguts "Vielfalt, Eigenart und Schönheit von Natur und Landschaft" in der Planung [Assessment of the visual landscape. Basics and methods to handle "diversity, peculiarity and beauty of nature and landscape" in planning practice.]. Informationsdienst Naturschutz Niedersachsen 20 (1): 1-60. [in German]

Kühne O (2006). Landschaft in der Postmoderne. Das Beispiel des Saarlandes [Postmodern Landscape. The example of the Saarland]. Deutscher Universitätsverlag, Wiesbaden, Germany, pp. 348. [in German]

Lindemann-Matthies P, Briegel R, Schüpbach B, Junge X (2010). Aesthetic preference for a Swiss alpine landscape: The impact of different agricultural land-use with different biodiversity. Landscape and Urban Planning 98 (2): 99-109. doi: 10.1016/j.landurbplan.2010.07.015

Lindenau G (2002). Die Entwicklung der Agrarlandschaften in Südbayern und ihre Beurteilung durch die Bevölkerung [The development of the agricultural areas in southern Bavaria and their appreciation by the public]. Franziska Land Verlag, Berlin, Germany, pp. 304. [in German]

Nohl W (2001). Sustainable landscape use and aesthetic perception-preliminary reflections on future landscape aesthetics. Landscape and Urban Planning 54 (1-4): 223-237. - doi: 10.1016/
S0169-2046(01)00138-4

Nitsch J, Pregger T, Scholz Y, Naegler T, Sterner M, Gerhardt N, van Oehsen A, Pape C, SaintDrenan, YM (2010). Langfristszenarien und Strategien für den Ausbau der erneuerbaren Energien in Deutschland bei Berücksichtigung der Entwicklung in Europa und global. Leitstudie 2010 [Long-term scenarios and strategies for the expansion of renewable energies in Germany]. DLR, Fraunhofer IWES, IFNE, pp. 201. [in German]

Palang H, Sooväli H, Antrop M, Setten G (2010). European rural landscapes. Persistence and change in a globalising environment. Springer, Dordrecht, The Netherlands, pp. 482.

Pott R (1999). Lüneburger Heide, Wendland und Nationalpark Mittleres Elbtal [Lüneburg Heath, Wendland and national park Mittleres Elbtal]. Ulmer, Stuttgart, Germany, pp. 256. [in German] Schüpbach B, Junge X, Briegel R, LindemannMatthies P, Walter T (2009). Aesthetische Bewertung landwirtschaftlicher Kulturen durch die Bevölkerung [Aesthetic assessment of agricultural crops by the public]. ART-Schriftenreihe 10, Zurich, Switzerland, pp. 122. [in German] Statistical Office North (2009). Statistical Office for Hamburg and Schleswig-Holstein. Web site. [online] URL: http://www.statistik-nord.de/ Strohm K, Schweinle J, Liesebach M, Osterburg B, Rödl A, Baum S, Nieberg H, Bolte A, Walter K (2012). Kurzumtriebsplantagen aus ökologischer und ökonomischer Sicht [Short rotation coppice from an ecological and economic perspective]. Arbeitsberichte aus der vTI-Agrarökonomie, 2012.6, Braunschweig, Germany, pp. 86. [in German]

Thrän D, Edel M, Pfeifer J, Ponitka J, Rode M, Knispel S (2011). Identifizierung strategischer Hemmnisse und Entwicklung von Lösungsansätzen zur Reduzierung der Nutzungskonkurrenz beim weiteren Ausbau der Biomassenutzung [Identification of strategic barriers and development of possible approaches to reduce competing uses in the bioenergy sector]. DBFZ Report Nr. 4 (4), Leipzig, Germany, pp. 193. [in German]

TLL (2007). Abschlussbericht Verbundvorhaben: Energiepflanzen für die Biogasproduktion [Final report: Energy crops for biogas production]. Agricultural Institute of the State of Thüringen, Jena, Germany, pp. 72. [in German]

Tuan YF (1977). Space and place. The perspective of experience. University of Minnesota Press, Minneapolis, MN, USA, pp. 496.

Tveit MS (2009). Indicators of visual scale as predictors of landscape preference; a comparison between groups. Journal of Environmental Management 90 (9): 2882-2888. - doi: 10.1016/j. jenvman.2007.12.021

Ulrich RS (1986). Human responses to vegetation and landscape. Landscape and Urban Planning 13: 29-44. - doi: 10.1016/0169-2046(86)900058 